\title{
Motivasi Penderita yang Kehilangan Gigi terhadap Penggunaan Gigi Tiruan
}

\author{
Brigita B. Rumambi, Vonny N. S. Wowor, Krista V. Siagian
}

Program Studi Pendidikan Dokter Gigi Fakultas Kedokteran Universitas Sam Ratulangi Manado, Indonesia

Email: bulanrrumambi@yahoo.com

\begin{abstract}
Denture wearing in society is influenced by several factors, one of which is motivation that can influences the mindset of individuals in decision making. This study was aimed to obtain the description of motivation among denture wearers. This was a literature review study using content analysis. There were four literatures on related topics obtained from the Google Scholar database, PubMed, and Garba Rujukan Digital. The results showed that in general, the external motivation of denture wearers was categorized as moderate, consisted of family support, environment, media, and health facilities. Meanwhile, the internal motivation was categorized as high, consisted of self-perception, interest, need, and expectation. In conclusion, motivations of patients with tooth loss to wear dentures consisted of extrinsic motivation which included the environment, information media, and health facilities, and the intrinsic motivation which included knowledge, self-perception, needs, interests, and expectation.
\end{abstract}

Keywords: motivation; denture wearers

\begin{abstract}
Abstrak: Penggunaan gigi tiruan pada masyarakat dipengaruhi oleh beberapa faktor salah satunya ialah motivasi yang dapat memengaruhi pola pikir individu dalam pengambilan keputusan. Penelitian ini bertujuan untuk mendapatkan gambaran motivasi penggunaan gigi tiruan. Jenis penelitian ialah studi pustaka dengan menggunakan content analysis. Terdapat empat pustaka mengenai topik terkait, diperoleh dari database Google scholar, PubMed, dan Garba Rujukan Digital. Hasil penelitian mendapatkan motivasi ekstrinsik penderita yang kehilangan gigi dengan penggunaan gigi tiruan umumnya tergolong sedang meliputi dukungan keluarga, lingkungan, media, dan fasilitas kesehatan sedangkan motivasi internal tergolong tinggi meliputi persepsi diri, minat, kebutuhan, dan harapan. Simpulan penelitian ini ialah motivasi penderita yang kehilangan gigi terhadap penggunaan gigi tiruan terdiri dari motivasi motivasi ekstrinsik yang meliputi lingkungan, media informasi dan fasilitas kesehatan dan motivasi intrinsik yang meliputi pengetahuan, persepsi diri, kebutuhan, minat, dan harapan.
\end{abstract}

Kata kunci: motivasi; pengguna gigi tiruan

\section{PENDAHULUAN}

Kesehatan gigi dan mulut merupakan faktor penentu berfungsinya proses mastikasi, estetik, dan artikulasi. Pemeliharaan kesehatan gigi dan mulut yang kurang dapat menyebabkan masalah dalam kesehatan gigi dan mulut. Beberapa masalah tersebut seperti trauma, karies, dan penyakit periodontal yang dapat menyebabkan kehilangan gigi. 1 ,
Kehilangan gigi mengakibatkan beberapa kondisi yang terjadi antara lain migrasi, rotasi, dan beban berlebih pada jaringan pendukung sehingga kondisi tersebut akan menimbulkan gangguan fungsi artikulasi dan mastikasi. ${ }^{1}$ Riset Kesehatan Dasar 2018 menunjukkan angka kehilangan gigi di Indonesia sebesar 19\%, namun persentase penggunaan gigi tiruan sebesar $1,4 \%$ masyarakat Indonesia. ${ }^{2}$ Hal ini menunjukkan 
kurangnya penggunaan gigi tiruan.

Penggunaan gigi tiruan pada masyarakat dipengaruhi oleh beberapa faktor salah satunya ialah motivasi. Motivasi dapat memengaruhi pola pikir individu dalam pengambilan keputusan. ${ }^{3}$ Motivasi terbagi dua, yaitu motivasi ekstrinsik dan motivasi intrinsik. Motivasi ekstrinsik merupakan dorongan karena adanya perangsang dari luar sedangkan motivasi intrinsik ialah dorongan berasal dari dalam diri sendiri. Faktor pendorong yang memengaruhi motivasi intrinsik terdiri atas pengetahuan, kebutuhan, dan gambaran diri serta motivasi ekstrinsik terdiri atas lingkungan, fasilitas dan media. Penggunaan gigi tiruan merupakan sikap sadar dan peduli akan kepentingan kesehatan gigi dan mulut yang dapat berasal dari motivasi intrinsik dan ekstrinsik. ${ }^{3-5}$

Berdasarkan hal-hal yang telah diuraikan maka penulis terdorong untuk mengetahui gambaran motivasi individu yang kehilangan gigi terhadap penggunaan gigi tiruan.

\section{METODE PENELITIAN}

Penelitian ini merupakan suatu literature review dengan menggunakan content analysis. Data sekunder diperoleh dari pencarian pustaka menggunakan tiga data base yaitu Google Scholar, PubMed, dan Garba Rujukan Digital. Kriteria inklusi yang digunakan yaitu terbitan 10 tahun terakhir, tersedia full text, berbahasa Indonesia dan Bahasa Inggris, jenis pustaka merupakan penelitian cross-sectional study, case control study, dan cohort study.

\section{HASIL PENELITIAN}

Penelitian ini merupakan literature review yang menggunakan data sekunder bersumber dari jurnal, artikel, dan buku teks yang membahas mengenai motivasi penderita yang kehilangan gigi terhadap penggunaan gigi tiruan dan diakses melalui internet. Peneliti memperoleh empat pustaka yang memenuhi kriteria penelitian. Tabel 1 memperlihatkan karakteristik keempat literatur yang dipergunakan sebagai data penelitian.

Tabel 1. Karakteristik literatur yang dipergunakan sebagai data penelitian

\begin{tabular}{|c|c|c|c|}
\hline $\begin{array}{c}\text { Peneliti dan } \\
\text { Tahun }\end{array}$ & Judul & $\begin{array}{l}\text { Metode dan } \\
\text { Sampel }\end{array}$ & Rangkuman Hasil \\
\hline $\begin{array}{l}\text { Sukini et al, } \\
2014 .^{6}\end{array}$ & $\begin{array}{l}\text { Motivasi internal dan eksternal } \\
\text { pemakaian gigi tiruan pada } \\
\text { paguyuban lansia "sehat bugar" } \\
\text { Semarang }\end{array}$ & $\begin{array}{l}\text { Observasional } \\
\text { dengan pende- } \\
\text { katan cross } \\
\text { sectionnal, } 67 \\
\text { sampel }\end{array}$ & $\begin{array}{l}\text { Pada paguyuban lansia "sehat bugar" } \\
\text { Semarang terdapat hubungan bermakna } \\
\text { antara motivasi internal dengan pemakaian } \\
\text { gigi tiruan tetapi tidak terdapat hubungan } \\
\text { bermakna antara motivasi eksternal dengan } \\
\text { pemakaian gigi tiruan }\end{array}$ \\
\hline $\begin{array}{l}\text { Ikhsan et al, } \\
2018 .^{7}\end{array}$ & $\begin{array}{l}\text { Pengaruh motivasi ekstrinsik } \\
\text { terhadap tingkat kepatuhan } \\
\text { pemakaian gigi tiruan lepasan }\end{array}$ & $\begin{array}{l}\text { Deskriptif } \\
\text { analitik dengan } \\
\text { pendekatan } \\
\text { cross sectional, } \\
81 \text { sampel }\end{array}$ & $\begin{array}{l}\text { Terdapat pengaruh motivasi ekstrinsik ter- } \\
\text { hadap tingkat kepatuhan pemakai gigi } \\
\text { tiruan lepasan di Kelurahan Batu Kota } \\
\text { Manado }\end{array}$ \\
\hline $\begin{array}{l}\text { Saragih A, } \\
\text { Hutahuruk } \\
\text { DG } \\
2019.8\end{array}$ & $\begin{array}{l}\text { Gambaran pengetahuan dan } \\
\text { motivasi terhadap pemakaian } \\
\text { gigi tiruan pada usia } 40-60 \text { tahun } \\
\text { di Jalan Kapten Muslim Helvetia } \\
\text { Kota Medan }\end{array}$ & $\begin{array}{l}\text { Deskriptif } \\
\text { dengan } \\
\text { pendekatan } \\
\text { cross sectional, } \\
30 \text { sampel }\end{array}$ & $\begin{array}{l}\text { Motivasi untuk memakai gigi tiruan pada } \\
\text { masyarakat usia } 40-60 \text { tahun di jalan Kapten } \\
\text { Muslim Helvetia Kota Medan, memiliki } \\
\text { motivasi tinggi }\end{array}$ \\
\hline $\begin{array}{l}\text { Dewi K et al, } \\
2017 .^{9}\end{array}$ & $\begin{array}{l}\text { Correlation between patients } \\
\text { with partial tooth loss charac- } \\
\text { teristics and patients motivation } \\
\text { to use dentures at RSGM Jember } \\
\text { University }\end{array}$ & $\begin{array}{l}\text { Observasional } \\
\text { analitik dengan } \\
\text { pendekatan } \\
\text { cross sectional, } \\
30 \text { sampel }\end{array}$ & $\begin{array}{l}\text { Regio dan posisi gigi yang hilang meme- } \\
\text { ngaruhi motivasi pasien yang menggunakan } \\
\text { gigi tiruan di RSGM Universitas Jember }\end{array}$ \\
\hline
\end{tabular}




\section{BAHASAN}

Motivasi merupakan dorongan psikologis yang menggerakkan seseorang dalam tindakan dan perilaku. Salah satu faktor yang memiliki peranan besar dalam penggunaan gigi tiruan yaitu motivasi. Individu yang menggunakan gigi tiruan memiliki motivasi tertentu sehingga apa yang diharapkan dapat tercapai setelah menggunakan gigi tiruan tersebut. ${ }^{6}$

Penelitian pertama dilakukan oleh Sukini et $\mathrm{al}^{6}$ pada paguyuban lansia "Sehat Bugar" Semarang. Hasil penelitian ini menunjukkan motivasi eksternal tidak berhubungan bermakna dengan penggunaan gigi tiruan $(\mathrm{p}=0,604)$, dan motivasi ekstrinsik tergolong sedang sebanyak $44,8 \%$ responden. Motivasi eksternal yang diteliti meliputi dukungan keluarga, lingkungan, media, dan fasilitas pelayanan kesehatan. Dukungan keluarga dalam hal ini memberikan informasi tentang penggunaan gigi tiruan dan menyarankan penggunaan gigi tiruan. Lingkungan turut berpengaruh dalam menentukan penggunaan gigi tiruan saat lingkungan tempat tinggal sudah banyak individu yang menggunakan gigi tiruan. Terdapatnya media yang menginformasikan tentang kesehatan gigi dan penggunaan gigi tiruan serta fasilitas pelayanan kesehatan yang cukup memadai serta informasi kesehatan mengenai penggunaan gigi tiruan. Pada penelitian ini, motivasi intrinsik berhubungan bermakna dengan penggunaan gigi tiruan $(\mathrm{p}=0,012)$ dan motivasi internal tergolong tinggi sebanyak $68,7 \%$ responden. Motivasi internal yang diteliti meliputi persepsi diri, minat, kebutuhan, dan harapan. Persepsi diri pada penelitian ini yaitu perasaan rendah diri karena kehilangan gigi serta perasaan lebih baik menggunakan gigi tiruan, kebutuhan mengenai gigi tiruan untuk aktifitas sehari-hari, dan harapan dengan menggunakan gigi tiruan akan mengatasi hambatan yang muncul sebelum menggunakan gigi tiruan. Hasil penelitian tersebut sejalan dengan penelitian yang dilakukan oleh Tulandi et al ${ }^{10}$ di Manado mengenai persepsi penggunaan gigi tiruan yang melaporkan adanya persepsi diri untuk mengatasi akibat kehilangan gigi, serta penelitian yang dilakukan oleh de Siqueira et al $^{11}$ di Brazil dan Zaied dan Saadaldin ${ }^{12}$ di Arab yang mendapatkan harapan dan kebutuhan penggunaan gigi tiruan.

Penelitian kedua yang dilakukan oleh Ikhsan et $\mathrm{al}^{7}$ di Manado menunjukkan adanya pengaruh motivasi eksternal terhadap tingkat kepatuhan pemakai gigi tiruan dengan hasil uji regresi sederhana $\mathrm{p}=0,000$. Pada penelitian tersebut motivasi ekstrinsik tergolong sedang sebanyak $60,5 \%$ responden. Motivasi ekstrinsik yang diteliti meliputi keluarga, lingkungan, media, dan fasilitas. Keluarga maupun lingkungan dalam penelitian ini memiliki anggapan bahwa gigi yang hilang ialah hal yang tidak wajar sehingga perlu menggunakan gigi tiruan. Informasi dari media cetak, media online, atau media elektronik memberikan informasi tentang dampak tidak menggunakan gigi tiruan serta fungsi gigi tiruan. Fasilitas kesehatan dalam penelitian tersebut memberikan penyuluhan serta edukasi dari tenaga kesehatan yang memadai.

Penelitian ketiga yang dilakukan oleh Saragih dan Hutahuruk ${ }^{8}$ di Medan. Hasil penelitian tersebut menunjukkan adanya motivasi tinggi sebanyak $46,7 \%$ responden dalam penggunaan gigi tiruan. Motivasi penggunaan gigi tiruan dalam penelitian tersebut dipengaruhi oleh beberapa faktor yaitu pengetahuan, kebutuhan, serta dukungan dari keluarga atau orang sekitar. Pengetahuan mengenai efek dari kehilangan gigi, juga fungsi penggunaan gigi tiruan, kebutuhan untuk pengunyahan bicara, serta memperbaiki penampilan, dan dukungan dari keluarga atau orang sekitar untuk menggunakan gigi palsu turut berperan. Sejalan dengan penelitian Jatuadomi et $\mathrm{al}^{13}$ di Manado disebutkan bahwa penggunaan gigi tiruan berhubungan dengan estetik penampilan sehingga mengembalikan rasa percaya diri, serta penelitian yang dilakukan Pratiwi $^{14}$ di Palembang yang menyatakan bahwa penggunaan gigi tiruan untuk mengembalikan fungsi gigi yaitu untuk memenuhi kebutuhan fungsi pengunyahan dan fungsi bicara.

Penelitian yang keempat dilakukan oleh Dewi et al $^{9}$ di Jember menunjukkan bahwa 
motivasi penggunaan gigi tiruan dapat dipengaruhi oleh regio atau posisi kehilangan gigi $(p=0,115)$. Hasil penelitian tersebut menunjukkan regio atau posisi anterior kehilangan gigi dapat memotivasi individu dalam penggunaan gigi tiruan untuk memperbaiki penampilan. Motivasi intrinsik meliputi pengetahuan dan kebutuhan serta motivasi ekstrinsik meliputi fasilitas kesehatan dan lingkungan. Tingkat pengetahuan mengenai kehilangan gigi dan fungsi pengunaan gigi tiruan serta juga kebutuhan untuk pengunyahan serta fungsi estetik penggunaan gigi tiruan, juga fasilitas kesehatan yang memadai dan lingkungan menjadi salah satu faktor motivasi dalam penggunaan gigi tiruan

Penelitian ini memiliki keterbatasan dikarenakan kurangnya referensi, perbedaan jumlah sampel, perbedaan usia, serta perbedaan latar belakang ekonomi dan sosial.

\section{SIMPULAN}

Motivasi ekstrinsik yang mendorong individu kehilangan gigi terhadap penggunaan gigi tiruan meliputi lingkungan, fasilitas kesehatan, dan media informasi sedangkan motivasi intrinsik meliputi pengetahuan, persepsi diri, kebutuhan, minat, dan harapan

\section{Konflik Kepentingan}

Penulis menyatakan tidak terdapat konflik kepentingan dalam studi ini.

\section{DAFTAR PUSTAKA}

1. Gunadi HA, Margo A, Burhan LK, Suryatenggara F, Setiabudi I. Ilmu Geligi Tiruan Sebagian Lepasan Jilid 1. Jakarta: Hipokrates, 2012.

2. Departemen Kesehatan Republik Indonesia. Laporan Riset Kesehatan Dasar Nasional 2018. Jakarta: Badan Penelitian dan Pengembangan Kesehatan, 2019.

3. Sumadi S. Psikologi Pendidikan. Depok: PT Raja Grafindo Persada, 2015; p. 72-3.

4. Rohmalina W. Psikologi Bejajar. Depok: PT Raja Grafindo Persada, 2016; p. 127-9.

5. Taufik. Motivasi dan Faktor-faktor yang Mempengaruhinya. Bandung: Pustaka Setia, 2007.
6. Sukini, Saptiwi B, Jati WDU, Nastiti ED. Motivasi internal dan eksternal pemakaian gigi tiruan pada paguyuban lansia "Sehat Bugar" Poltekkes Semarang. Jurnal Kesehatan Gigi. 2015;2(1):47-56.

7. Ikhsan NP, Wowor VNS, Pangemanan HCP. Pengaruh motivasi ekstrinsik terhadap tingkat kepatuhan pemakaian gigi tiruan lepasan di Kelurahan Batu Kota. e-GiGi. 2018;6(2):

8. Saragih A, Hutahuruk DG. Gambaran pengetahuan dan motivasi terhadap pemakaian gigi tiruan pada usia 40-60 tahun di Jalan Kapten Muslim Helvetia Kota Medan. Jurnal Ilmiah Pannmed. 2019; 14(1):101-4.

9. Dewi K, Rahardyan P, Asti W. Correlation betwen patients with partial tooth loss characteristics and patients' motivation to use dentures at RSGM Jember University. 2017. Available from: https://jurnal.unej.ac.id.

10. Talundi JDG, Tendean L, Siagian KV. Persepsi penggunaan gigi tiruan lepasan terhadap fungsi estetik dan fonetik di komunitas lansia Gereja Internasional Full Gospel Fellowship Manado. eGiGi. 2017;5(2).

11. de Siqueira GP, dos Santos MBF, dos Santos JFF, Marchini L. Patient's expectation and statisfaction with removable dental prosthesis therapy and correlation with patient's evaluation of the dentist. Acta Odontologica Scandinavica. 2013; 71(1):210-4.

12. Zaied B, Saadaldin AS. Infuencing factors on patients' expectation and statisfaction with complete denture. EC Dental Science. 2016;6(3):1316-20.

13. Jatuadomi, Gunawan PN, Siagian KV. Alasan pemakaian gigi tiruan lepasan pada pasien poliklinik gigi di BLU RSUP Prof. Dr. R. D. Kandou Manado. eGiGi. 2016;4(1):40-4.

14. Pratiwi R. Persepsi penggunaan gigi tiruan sebagian lepasan akrilik dalam memenuhi kebutuhan pemakaian gigi tiruan pada pasien di Poli Gigi Rumah Sakit Mohammad Hoesin Palembang [Electronic Thesis and Dissertations/ ETD]. Palembang: Universitas Sriwijaya; 2016. 